\title{
Assessing the abundance of freshwater turtles in an Australian urban landscape
}

\author{
RAYMONDE DE LATHOUDER \\ DARRYL N. JONES \\ STEPHEN R. BALCOMBE
}

Centre for Innovative Conservation Strategies and

Australian Rivers Institute

Griffith University, Nathan, Qld 4111, Australia.

\section{Correspondence:}

\section{Darryl Jones}

Centre for Innovative Conservation Strategies,

Griffith University, Nathan, Qld 4111, Australia.

Email: D.Jones@griffith.edu.au

Phone: (07) 3735 7451; Fax: (07) 37353512.

\begin{abstract}
:
Although interest in the ecological impacts of urbanisation has increased, very little is known about freshwater turtles in urban landscapes, particularly in Australia. This study investigated the abundance and diversity of turtles in lakes in an urbanised subtropical landscape (Brisbane, Australia). It was found that turtles were abundant throughout the lakes surveyed, with four native species and one introduced species being detected. A total of 371 individuals captured, $77.7 \%$ of which were Brisbane River turtle (Emydura macquarii signata). The lakes surveyed were estimated to support a population of 63-269 individuals for all the species combined with most lakes containing less than 100. Turtle demographics may be classed into three stages of population growth: recovery or nascent; intermediate; and climax. Turtle reproductive success was a major concern for the survival of turtles in urban areas. Continued monitoring is needed to establish if population declines are occurring. Furthermore, levels of predation on nests and juveniles in urban landscapes needs to further investigated. This study suggests that turtles while are persisting in this urban environment of Australia the pressures of urbanisation, such as habitat loss, increased predation and pollution of waterways may pose on-going risks to their survival.
\end{abstract}

Running Head: Abundance of urban turtles in Australia

Keywords: $\quad$ Turtles, urban landscape, urban lakes, abundances 


\section{Introduction}

Urbanisation has lead to the homogenization, fragmentation, isolation and degradation of physical environments with significant impacts on local biodiversity (Forman et al. 2003; McKinney 2006). Habitat fragments are often dispersed widely throughout the landscape, isolating populations within relatively small habitat patches (Hanski 1999; McKinney 2006). Isolation in urban areas results in decreased movement between subpopulations and increases the risk of population extinction (Hanski 1999). Many habitat fragments in urban areas are not large enough to support populations of some species (Chelazzi et al. 2006). Urban areas are also associated with new threats such as mortality from dogs, cats and wildlife-vehicle collisions (Forman et al. 2003; Aresco 2005a).

The negative influences of urbanisation has been particularly strong in relation to waterbodies such as streams, rivers and lakes (Bodie 2001). Increased impervious surfaces in urban areas has lead to considerable changes in the hydrology and geomorphology of streams (Paul and Meyer 2001). Increased runoff, together with discharges from industrial and commercial zones, have increased the amount of nutrients, metals, pesticides and other contaminants found in waterways (Walsh et al. 2001). Loss of vegetation in catchment areas, particularly of riparian vegetation, decreases the amount of carbon and increases runoff entering the waterway (Paul and Meyer 2001; Urban et al. 2006). These changes to urban waterways can affect many organisms, particularly if they are sensitive to changes in their environment or are dependent on specialised habitat requirements (Urban et al. 2006). Urbanisation has been shown to cause a reduction in the diversity and abundance of a wide range of native species in waterways (Arthington et al. 1983). Moreover, native species are often out-competed by introduced species which are more tolerant of environmental changes and have high reproductive potential (Arthington et al. 1983).

Australia supports a relatively large diversity of freshwater turtle species, some of which are known to occur in urban lakes (Cann 1998). However, very little is known about the ecology or conservation status of turtles in urbanised landscapes in Australia. Many species of turtles have limited dispersal capabilities, with populations easily becoming isolated by barriers such as dams and roads (Gibbs and Shriver 2002). They are an important part of food webs, as top predators or by having a major influence on energy transfer via their often large biomass (Chessman 1984; Spencer et al. 1998). In North America, numerous studies (Rubin et al. 2001; Spinks et al. 2003; Conner et al. 2005) on turtles in urban areas have discerned significant declines in the several species and populations. Such declines have been attributed to decreased nesting success (Conner et al. 2005), an increase in deaths from road accidents (Gibbs and Shriver 2002; Aresco 2005b) and over-exploitation by humans (Gibbons et al. 2001). In Australia, the impact of introduced red foxes Vulpes vulpes (Spencer and Thompson 2005) and commercial fish traps (Lowry et al. 2005) on turtle populations has been investigated, but there has been little attention to the status of turtles in urban areas.

The distribution and abundance of turtles in any of the urbanised areas of Australia remains largely unknown. In South-East Queensland, the most rapidly growing region in Australia (Australian Bureau of Statistics 2007), large numbers of natural and artificial lakes exist. Many of these lakes have been reported as supporting freshwater turtles (Thomson 1978; Stewart 1996), including the Brisbane River turtle (Emydura macquarii signata), snake-necked turtle (Chelodina longicollis), broad-shelled turtle (Chelodina expansa) and saw-shelled turtle (Wollumbinia latisternum). However, nothing is known of their abundance and diversity.

The present study aimed to undertake a preliminary assessment of the status of native species of freshwater turtles in relation to the potential stresses brought about by urbanisation by investigating the diversity and relative abundance of freshwater turtles in urban lakes near Brisbane, the largest city in South-East Queensland. This study represents the first detailed investigation into the biodiversity and abundance of freshwater turtles in an urban area in Australia. The specific objectives of the study were to:- 1.Investigate the diversity and abundance of species in urban lakes; 2 . Estimate the total population size using markrecapture data; 3.Describe the size distribution of turtles found in urban lakes; and 4. 
Investigate whether the abundance of turtles is correlated with physical and/or biological habitat characteristics.

\section{Methods}

\section{Study sites}

The study was carried out in lakes located within the suburbs of Brisbane, Australia (latitude $27^{\circ} 28^{\prime}$ S, longitude $158^{\circ} 02^{\prime} \mathrm{E}$ ). The size and location of most lakes within Greater Brisbane region was informally surveyed using a Brisbane street directory (UBD 2003) from which a subset of eight was selected as being representative. These sites were selected for intensive study on the basis of the following criteria: (1) easy accessibility; (2) situated on public land; (3) being within the range of 0.3-5ha in area; and (4) having clearly defined boundaries (i.e. not flowing rivers or creeks). The area of each lake was estimated using Google Earth (Table 1). Several of the lakes, including Edenbrooke Estate, Gainsborough Park and Lakewood Estate, had been artificially created within the last 15 years on creek or drainage lines (Hassall 2000; Your Suburb: Mackenzie 2007). Mt-Coot-tha Botanical Gardens was also artificially created 37 years ago by damming a small gully. The other lakes used in the study are presumed to have existed as lakes, lagoons or creeks previous to modifications into their current form (Table 1).

\section{Trapping procedure}

Field work was conducted between $4^{\text {th }}$ October 2006 and $16^{\text {th }}$ February 2007 (totalling 62 field days) to coincide with the metabolically active season of the turtles. Each of the eight lakes was visited at least six times to determine the abundance and distribution of freshwater turtles in Brisbane. Six additional days of trapping were undertaken at Sherwood Arboretum to compare the trapping efficiencies of two trap designs (see de Lathouder 2007). Underwood Park had an extra six days of trapping, undertaken by Biosecurity Queensland from the Department of Natural Resources and Water (NRW), as part of the introduced red-eared slider (Trachemys scripta elegans) trapping program. This trapping at Underwood Park occurred from $16^{\text {th }}$ to $26^{\text {th }}$ October 2006 and on $7^{\text {th }}$ March 2007 using similar trapping methods.

Both fyke nets and cathedral traps were used to sample turtles. Fyke nets are commonly used to capture aquatic turtles and are of similar design to hoop nets (Legler 1960; Ream and Ream 1966). The cathedral trap is a relatively more recent trap design found to be effective for trapping turtles (NRW 2006) and is similar to a trap designed by Kuchling (2003). Traps were deployed in the early morning and removed after approximately six hours. (For more details on trapping methods see de Lathouder 2007).

Traps were collected and turtles were place in large container prior to measurement and were released within 1.5 hours of the trap being removed from the water. Turtles were marked for individual identification by notching the marginal scutes of the carapace with a small ' $\mathrm{V}$ ' (Cagle 1939). Newly hatched individuals were not marked due to their small size and the risk of injury. The species of each turtle was recorded using the diagnostic features described in Cogger (2000). The maximum carapace length and width, maximum plastron length and width, shell height and extended tail length were measured using a vernier calliper (to the nearest $0.1 \mathrm{~cm}$ ). Each turtle was also weighed using a spring balance. The sex of each individual was determined from the tail length (Cann 1998). Males of all species (except the snake-necked turtle) had a tail length of almost double that of an equal-sized conspecific female (carapace length 7-13 cm). Females generally had a tail length of 4-8cm, while turtles with a carapace length $<15 \mathrm{~cm}$ and a tail length of $<4 \mathrm{~cm}$ were as juvenile. The presence of eggs was assessed in females by manual external examination of the cavity in front of the hind legs.

\section{Habitat characteristics}


During the first trapping session a detailed assessment of 20 habitat variables was conducted for each lake. The average depth of the lake was estimated from personal experience of the incline and depth of the water where traps were set, or from a published source where available. The depth was classed as: (i) less than 1m; (ii), 1-2m; (iii) 2-3m; and (iv) greater than $3 \mathrm{~m}$. The area of each lake was accurately measured using the spatial function of Google Earth.

The riparian vegetation present within $2 \mathrm{~m}$ of the shoreline was categorised into five broad groups: grasses, shrubs, trees, rushes and herbs, and the percentage cover estimated by eye for each category. Similarly, aquatic vegetation was categorised into four broad groups (Shirley et al. 2003). The total percentage cover of aquatic vegetation was estimated visually as well as the percentage cover for each type of vegetation. The number of emergent logs and rocks were also counted as these represent potential basking spots available to the turtles. A qualitative measure of pollution level was included as a measure of the amount of refuse that could be seen and the level of disturbance level was used as a surrogate for human activity associated with the lake. These factors were categorised subjectively from very low to very high. A quantitative measure of disturbance was also recorded by noting all people (walkers, runners, dogs, children, bikes, people feeding wild animals, etc.) within $100 \mathrm{~m}$ of the lake. This was then divided by the number of hours spent at the lake to obtain the number of people present per hour. It is important to note that despite the fact that it is an average, the number of people detected was highly uneven with peaks at around 06:00 and 16:00 for most sites. The occurrence of supplementary feeding of turtles or other animals was also noted. The fish caught in the traps were identified to species using Allen et al. (2002) and the number of each species was recorded.

\section{Data analysis methods}

Most statistical analyses were performed using the statistical program SAS system (SAS Institute 1999). The maturity (adults to juveniles), sex (males to females) and presence of eggs (females with eggs to females without eggs) frequencies for the remaining species were compared using $\mathrm{Chi}^{2}$ contingency table analysis. The differences in abundances of the four dominant species in the lakes, as well as the frequencies maturity, sex and presence of eggs were compared using $\mathrm{Chi}^{2}$ contingency table analysis. Due to low expected values, the likelihood ratio $\mathrm{Chi}^{2}$ was used for comparing the species abundance and egg presence frequencies. As a result of the low number of captures of the snake-necked turtle, it was not included in any analysis except overall counts of individuals.

A multiple regression model was used to investigate which habitat characteristics predicted the abundance and species of turtles and the mean number of observed turtles at each lake. The final model using stepwise selection was chosen on the basis of all variables in the model contributing to more than $10 \%$ of the total variation (as shown by the R-square value). The variables in the model include the habitat characteristic variables and summary statistics of the fish captured (total number of fish, total number of native and exotic fish, total number of species and number of native and exotic species).

Mark-recapture analysis was performed using the software Program MARK (White 2007). Mark-recapture data for each lake was used to find the estimated population size. CAPTURE analysis was performed using the 'appropriate' function to select the best model for each of lakes (including the Jack-knife, Null, Pollock and Otto, Generalized removal, Zippin and Darroch models).

\section{Results}

A total of 444 turtles were captured during the study. Of these, 73 were recaptures resulting in a total of 371 individual turtles consisting of four native species and one introduced species (Table 2). The majority of captures were of the Brisbane River turtle, with $77.7 \%$ of individuals captured. There was a significantly different ratio of adults and juveniles among the different species than expected $\left(\mathrm{Chi}^{2}=35.31, \mathrm{df}=3, \mathrm{p}=<0.0001\right.$ ). While the Brisbane River 
turtle had an almost equal ratio of adults and juveniles (1.5:1), the saw-shelled turtle and broad-shelled turtle had significantly more adults than juveniles with a ratio of 11.3:1 and 20:1 adults to juveniles respectively. For adult turtles there was relatively little variation in the ratio of males and females between species. Approximately 50\% of female Brisbane River turtles and saw-shelled turtles were found to be gravid, while no female broad-shelled turtles were.

\section{Comparison of turtles between lakes}

The total number of individuals captured varied greatly among the lakes (Figure 1), ranging from 86 for Minnippi Parklands to 14 for Mt Coot-tha Botanical Gardens. The abundance of each species varied considerably between the eight lakes (Likelihood ratio $\mathrm{chi}^{2}=125.56$, $\mathrm{df}=21, \mathrm{p}=<0.0001)$. The Brisbane River turtle was the most abundant species at all lakes except Mt Coot-tha Botanical Gardens which had similar numbers of saw-shelled turtles and Brisbane River turtles (Figure 1). Most lakes had two or three of the four native species with the snake-necked turtle being detected the least.

The ratio of adults to juveniles differed significantly between the different lakes $\left(\mathrm{Chi}^{2}=82.24, \mathrm{df}=7, \mathrm{p}=<0.0001\right)$ (Table 3). Sherwood Arboretum had the lowest proportion of juveniles (2.7\% of captures) while Gainsborough Park had the highest (72.2\%). The ratio of males to females varied significantly for the different lakes $\left(\mathrm{Chi}^{2}=19.96, \mathrm{df}=7\right.$, $\mathrm{p}=<0.0057$ )(Table 3). Dennis Lake recorded the highest percentage of males and Edenbrooke Estate recorded the lowest. Generally, the sex ratio appeared to be approximately 1:1. At the majority of lakes, less than $50 \%$ of females were gravid (Table 3 ).

The size distribution of males, females and juveniles at each lake is shown in Figure 2. Dennis Lake and Gainsborough Park supported distinctly younger populations, with the majority of individuals being less than $20 \mathrm{~cm}$ in length (Figure 2a and c). Lakewood Estate, Underwood Park and particularly Sherwood Arboretum were found to have populations biased towards an older, mature population (Figure 2d, g and h). Only Edenbrooke Estate and Minnippi Parklands appeared to have relatively evenly spread of size distributions for adults and juveniles (Figure $2 \mathrm{~b}$ and e).

Cumulative capture curves (Figure 3) indicated that further trapping effort was needed to obtain reliable estimations of the population size at all lakes, except Mt Coot-tha Botanical Gardens where the curves reached an asymptote (Figure 3f). As new individuals continued to be captured at most of the lakes, the populations were likely to be larger than that observed. For example, although both female and hatchling Brisbane River turtles were captured at Mt Coot-tha Botanical Gardens, no male Brisbane River turtles were detected. The population estimates for each lake were variable and depended heavily upon the number of individuals captured and the number of recaptures within each species at each lake (Table 4). At most lakes the population estimates for the broad-shelled turtle and saw-shelled turtle did not vary greatly from the number of captured (Table 4), due to the low number of captures and low or lack of recaptures. Most of the lakes were estimated to have populations at least double the size of the captured population. Population estimates ranged between 272 for Minnippi Parklands and 25.5 for Mt Coot-tha Botanical Gardens.

\section{Habitat characteristics correlations}

There was a significant relationship between the habitat characteristics and the total number of turtles captured $\left(\mathrm{f}=26.15, \mathrm{df}=2, \mathrm{p}=0.0022, \mathrm{R}^{2}=0.9127\right)$. The total number of turtles captured at each lake was positively related to the percentage of herb cover in the riparian zone and the level of disturbance (Figure 4a and b, respectively). Different habitat characteristics were found to best predict the total number of turtles captured for each species. For the Brisbane River turtle ( $\mathrm{f}=36.32, \mathrm{df}=2, \mathrm{p}=0.0011, \mathrm{R}^{2}=0.9356$ ), the percentage of herbs in the riparian zone were positively correlated to the number of turtles $(\mathrm{f}=15.47, \mathrm{df}=1, \mathrm{p}=0.0077$, Partial $\mathrm{R}^{2}=0.7205$ ) while the depth of the water was negatively correlated with the number of individuals $\left(\mathrm{f}=16.70, \mathrm{df}=2, \mathrm{p}=0.0095\right.$, Partial $\mathrm{R}^{2}=0.2151$ ). In other words, more Brisbane 
River turtles were captured in relatively shallow lakes that had a high percentage of herbs in the riparian zone. The percentage of shrubs in the riparian zone and the depth of the lake was positively related to the number of saw-shelled turtles found at each lake $(\mathrm{f}=28.86, \mathrm{df}=2$, $\mathrm{p}=0.0018, \mathrm{R}^{2}=0.9203$ ). The number of broad-shelled turtles was positively correlated with the number of introduced fish and the level of disturbance $\left(\mathrm{f}=142.71, \mathrm{p}=<0.0001, \mathrm{R}^{2}=0.9828\right.$ ).

\section{Discussion}

Although it is known that freshwater turtles do occur in South-East Queensland (Cann 1998; Cogger 2000), little information exists on how turtles have been impacted by urban development. This study has revealed that freshwater turtles have survived in urban areas despite the many pressures to which they are subjected. All species known to occur in the Brisbane area were detected during the study period. The majority of captures were of the Brisbane River turtle, either because it is more abundant or because it more readily enters the traps (Chessman 1988). The broad-shelled turtle is known to be relatively difficult to capture (Cann 1978), and is rarely caught in hoop nets (Legler 1978). Generally, it is thought that this is because their secretive behaviour and feeding style limits the amount of contact this species would have with the traps (Cann 1998). Nonetheless, even though the broad-shelled turtle was less captured than short-necked species, they contributed a significant proportion of all captures.

Most surprising was the lack of snake-necked turtles captured. Other studies have successfully captured large numbers of this species with hoop and fyke nets (Beumer et al. 1981; Chessman 1984) in similar habitats. This suggests that the lack of snake-necked turtles captured during the present study was due to their sparse distribution in the lakes sampled. Most of the studies that have captured large numbers of snake-necked turtles were carried out in the cooler regions of south-eastern Australia where there are fewer competing turtle species (Chessman 1988; Ross 2000). Another possibility is that the optimal physiological and ecological habitat for this species occurs mostly in south eastern Australia, while the warmer regions in Queensland represent the outer limits of their range (Cann 1998).

\section{Size distribution}

The percentage of juveniles present at each lake was highly variable. From the size distributions it can be seen that there are varying demographics of the turtle assemblages at different lakes. Turtle demographics can be classed into three stages of population growth: recovery or nascent; intermediate; and climax (Figure 5)(Georges et al. 2005). Both Dennis Lake and Gainsborough Park appear to have a recovering or nascent turtle assemblage with many juveniles, hatchlings and gravid females. Gainsborough Park has only recently been built (Table 1), resulting in an expanding population with a lot of juveniles and a few adult individuals immigrating to the lake. There is also concern that the management and removal of aquatic vegetation may have impacted the abundance of turtles at some of the lakes. To control the extent to which aquatic vegetation covers lakes, local councils spray with pesticides or mechanically remove the vegetation. It is not known how this affects turtle populations. A study by Booms (1999) found that many turtles were captured during the removal of weeds, although most were returned safely to the water. Although Dennis Lake was originally a natural lagoon, there are reports from local residents that turtles have been illegally fished in the past, which may explain the recovering size distribution.

The size distributions show that the turtle populations were at varying stages of growth. Despite the fact that Edenbrooke Estate was the 'youngest' of all the lakes (Table 1), it had an intermediate size distribution possibly due to colonisation from the connecting parts of the creek or introduction to the lake as unwanted pets, and subsequent population expansion through the availability of new resources. Minnippi Parklands also had an intermediate size distribution. Fishing is known to occur at the lake, which has been shown to have impact on the size distribution of turtles (White 2002). A high level of breeding activity including many juveniles, gravid females and several nests indicates a high level of 
recruitment potential into the turtle assemblage. Lakewood Estate and Underwood Park both had intermediate to climax size distributions, while the size distribution at Sherwood Arboretum had climaxed. These lakes, particularly Sherwood Arboretum, have limited reproductive success. However, it is unlikely that this was due to lack of breeding activity as nests and gravid females were observed at all of the climax turtle assemblages. Rather, predation on nests and hatchlings by species such as eels, foxes, water rats (Hydromys chrysogaster) and other rats (Rattus spp.) is thought to have significantly impacted the reproductive success of species of turtles at these sites (Thompson 1983; Cann 1998; Spencer et al. 2006). Local residents (personal records) at Sherwood Arboretum have also observed purple swamphens (Porphyrio porphyrio) and Australian white ibis (Threskiornis molucca) digging up nests and chasing hatchlings as they make their way to the water.

\section{Population estimation}

When conducting studies to determine the abundance of a species it is difficult to detect every individual in the population (Koper and Brooks 1998; Southwood and Henderson 2000). The cumulative individual curves obtained in this study indicated that for all lakes except Mt Coot-tha Botanical Gardens, the total number of captures was still increasing. This indicates that the total population size had not yet been reached (Southwood and Henderson 2000). Mark-recapture studies are often used to estimate the population size when the total population cannot be determined directly. In this study, the population estimates for each lake varied and depended heavily upon the number of individuals of each species that were captured and recaptured at each lake. The accuracy of the population estimates increases as the number of recaptures increases (Koper and Brooks 1998). As a result of the low number of captures and recaptures for some species, the precision of the population estimates at several of the lakes were severely reduced. The total estimated population size at the lakes ranged between 63 and 269 for all the species combined with most being under 100 individuals. This is similar to a study by White (2002) in rural waterholes of inland Queensland, Australia which found population sizes ranging between 22 and 190 individuals of the Cooper Creek turtle (Emydura macquarii). Trembath (2005) found considerably larger populations of Krefft's river turtle (Emydura macquarii krefftii) in Alligator Creek and Ross River near Townville, in tropical Queensland, with an estimated population of between 441 and 5342 individuals. However, as Trembath (2005) conducted their study in flowing rivers rather than isolated waterholes or lakes, it was expected that the population estimates would be larger.

\section{Habitat characteristics predicting turtle abundance}

The relative abundance of the turtles was positively attributed to the amount of vegetation in the riparian zone and level of disturbance. As both these variables appear to be relatively arbitrary (particularly the disturbance level as it is a qualitative measure of the number of human activity at the site), this shows that turtles inhabit urban areas regardless of any habitat features or the lake. Other studies have also found that many turtles species are hardy and versatile, surviving across a wide range of habitats (Chessman 1988; Cann 1998; Trembath 2005).

The abundance of each species in urban lakes was attributed to different habitat characteristics. Higher numbers of Brisbane River turtles were captured at lakes that were relatively shallow while the abundance of the broad-shelled turtle was positively associated with fish abundance. This may be in part explained by these turtles being known to be carnivorous (Georges 1982; Chessman 1983; Trembath 2005). However, high fish production is likely to indicate generally high lake primary and secondary production, hence, increasing food resources for all turtle species within such lakes.

\section{Conservation and management issues}


Although turtles around the world are increasingly affected by urbanisation (Spencer 2001; Spinks et al. 2003; Baldwin et al. 2004), the diversity and abundance of turtles in Brisbane does not appear to have been severely impacted. Studies in other urban areas, particularly in North America, have shown that increased predation and isolation and decreased terrestrial habitat has lead to declines in population numbers of many species of turtles (Mitchell 1988; Spencer 2001; Baldwin et al. 2004). A similar study in the urban landscape around Sydney, Australia, found that turtles were also successfully coping with the pressures of urbanisation (Ross 2000).

The climax size distributions that were observed at some of the lakes may indicate decreasing population sizes. Turtles are long-lived and the effect on diminished reproductive success may not be observed as a population decline until many years later (Belzer 2000). There is some concern about the populations at Sherwood Arboretum and Underwood Park, which may be declining or may decline in the future as a result of low levels of recruitment into the population. Protection of nests and hatchlings from predators may be a vital strategy to ensure the continued survival of turtle populations at some lakes in urban areas (Spencer 2001; Spencer et al. 2006).

A major concern for urban turtles is the modification or destruction of terrestrial habitat surrounding lakes (Semlitsch and Bodie 2003; Baldwin et al. 2004). Turtles require relatively undisturbed habitat surrounding lakes for nesting and hibernation (Burke and Gibbons 1995; Bodie 2001). The modification of habitats in parks and fragmentation of habitat by roads mean that many turtles cannot find adequate sites for nesting or hibernation (Burke and Gibbons 1995; Semlitsch and Bodie 2003).

Even though there were many turtles still present in urban lakes, direct impacts by humans was noticeable. For example, some dead turtles were discovered during the study. The causes of death were attributed to a collision with a car in one instance but remain unknown for the two other turtles. Several injuries were also observed on turtles, including damaged or abnormal eyes, absent limbs and damaged carapace or plastron. Injuries may have occurred from encounters with vehicles particularly lawnmowers, fishing lines or large animals such as dogs, goannas, other turtles and fish. Pollution of waterways remains a constant threat, as recently occurred in a creek in southern Brisbane when a petroleum tanker crashed and spilt over 340,000L of fuel onto the road and into $800 \mathrm{~m}$ of the local creek (The Courier-Mail 2-3 June 2007). Animals including ducks, turtles, water dragons, fish and frogs were killed, many within minutes of coming in contact with the petrol. Though such a spill is an extreme example of pollution in urban areas, it shows the magnitude of death that can occur when pollutants enter waterways. Lesser doses of pollutants may be affecting the survival and reproductive output of many species in many urban waterways.

This study shows that turtles are persisting in certain urban areas of Australia; however, the pressures of urbanisation, such as habitat loss, increased predation and pollution of waterways were also clearly evident at some lakes around Brisbane. The creation of water features in housing estates appears to be beneficial as it has provided new areas for many species, including turtles, to inhabit in urban landscapes. There is some concern for the long term survival of turtles at some lakes in urban areas, particularly lakes with climax population demographics, as low reproductive success many indicate a declining population. Future long term monitoring of populations is necessary to establish whether population declines are occurring. The level of predation on nests and juveniles in these urban landscapes also warrant further investigation.

\section{Acknowledgements}

This study was conducted with permission of the Queensland Environmental Protection Agency (permit no. WISP03891706). All methods used were approved by the Griffith University Animal Ethics Committee (AES/15/06/AEC). We thank the Brisbane City Council and Logan City Council for permission to conduct trapping on council land. Many thanks go to all the volunteers who assisted in the project. We are also grateful to the many community groups who assisted and supported the project. 


\section{References}

Allen GR, Midgley SH, Allen M (2002) Field guide to the Freshwater Fishes of Australia. CSIRO, Western Australian Museum, Perth, Australia

Aresco MJ (2005a) The effect of sex-specific terrestrial movements and roads on the sex ratio of freshwater turtles. Biological Conservation 123:37-44

Aresco MJ (2005b) Mitigation measures to reduce highway mortality of turtles and other herpetofauna at a North Florida lake. Journal of Wildlife Management 69:549-560

Arthington AH, Milton DA, McKay RJ (1983) Effects of urban development and habitat alterations on the distribution and abundance of native and exotic freshwater fish in the Brisbane region, Queensland. Austral Ecology 8:87-101

Australian Bureau of Statistics (2007) Regional Population Growth, Australia, 1996 to 2006, Cat. no. 3218.0. In. ABS, Canberra

Baldwin EA, Marchand MN, Litvaitis JA (2004) Terrestrial habitat use by nesting painted turtles in landscapes with different levels of fragmentation. Northeastern Naturalist 11:4148

Belzer B (2000) A nine year study of Eastern Box Turtle courtship with implications for reproductive success and conservation in a translocated population. Turtle and Tortoise Newsletter 6:17-26

Beumer JP, Burbury ME, Harrington DJ (1981) The capture of fauna other than fishes in eel and mesh nets. Australian Wildlife Research 8:673-677

Bodie JR (2001) Stream and riparian management for freshwater turtles. Journal of Environmental Management 62:443-455

Booms TL (1999) Vertebrates removed by mechanical weed harvesting in Lake Keesus, Wisconsin. Journal of Aquatic Plant management 37:34-36

Burke VJ, Gibbons JW (1995) Terrestrial buffer zones and wetland conservation: a case study of freshwater turtles in a Carolina Bay. Conservation Biology 9:1365-1369

Cagle FR (1939) A system for marking turtles for future identification. Copeia 1939:170-173

Cann J (1978) Tortoises of Australia. Angus and Robertson, Sydney

Cann J (1998) Australian freshwater turtles. Beaumont Publishing, Singapore

Chelazzi G, Naziridis T, Benvenuti S, Ugolini A, Crivelli AJ (2006) Use of river-wetland habitats in a declining population of the terrapin (Mauremys rivulata) along the Strymon River, northern Greece. Journal of Zoology In press

Chessman BC (1983) Observations on the diet of the broad-shelled turtle, Chelodina expansa Gray (Testudines : Chelidae). Australian Wildlife Research 10:169-172

Chessman BC (1984) Food of the snake-necked turtle, Chelodina longicollis (Shaw) (Testudines : Chelidae) in the Murray Valley, Victoria and New South Wales. Australian Wildlife Research 11:573-578

Chessman BC (1988) Habitat preferences of freshwater turtles in the Murray Valley, Victoria and New South Wales. Australian Wildlife Research 15:485-91

Cogger HG (2000) Reptiles and amphibians of Australia, 6th Edition edn. Reed New Holland, Sydney

Conner CA, Douthitt BA, Ryan TJ (2005) Descriptive ecology of a turtle assemblage in an urban landscape. American Midland Naturalist 153:428-435

de Lathouder RM (2007) Assessing the abundance of freshwater turtles in an urban landscape: A comparison of trapping and observational techniques. In: Centre for Innovated Conservation Strategies. Griffith University, Brisbane

Forman RTT, Sperling D, Bissonette JA, Clevenger AP, Cutshall CD, Dale VH, Fahrig L, France R, Goldman CR, Heanue K, Jones JA, Swanson FJ, Turrentine T, Winter TC (2003) Road ecology: science and solutions. Island Press, Washington

Georges A (1982) Diet of the Australian freshwater turtle Emydura krefftii (Chelonia : Chelidae), in an unproductive lentic environment. Copeia 1982:331-336

Georges A, White M, Guarino E, Fitzsimmons NN, Goodsell TL, Farrington L (2005) Dryland River Refugia Final Report: The Ecology of the Cooper Ck Turtle, Emydura macquarii. In. CRC for Freshwater Ecology, Canberra, Australia 
Gibbons JW, Lovich JE, Tucker AD, Fitzsimmons NN, Greene JL (2001) Demographic and ecological factors affecting conservation and management of the diamondback terrapin (Malaclemys terrapin). Chelonian Conservation and Biology 4:66-74

Gibbs JP, Shriver WG (2002) Estimating the effects of road mortality on turtle populations. Conservation Biology 16:1647-1652

Hanski I (1999) Metapopulation ecology. Oxford University Press, New York

Hassall DC (2000) Lakewood Park environmental management plan. In. Anembo Consultant Pty. Ltd., Commissioned by Brisbane City Council, Brisbane, Australia

Koper N, Brooks RJ (1998) Population-size estimators and unequal catchability in painted turtles. Canadian Journal of Zoology 76:458-465

Kuchling G (2003) A new underwater trap for catching turtles. Herpetological Review 34:126-128

Legler JM (1960) A simple and inexpensive device for trapping aquatic turtles. Proceedings of the Utah Acad. of Science Arts and Letters 37:63-66

Legler JM (1978) Observations on behaviour and ecology in an Australian turtle, Chelodina expansa (Testudines : Chelidae). Canadian Journal of Zoology 56:2449-2453

Lowry MB, Pease BC, Graham K, Walford TR (2005) Reducing the mortality of freshwater turtles in commercial fish traps. Aquatic Conservation: Marine and Freshwater Ecosystems 15:7-21

McKinney ML (2006) Urbanization as a major cause of biotic homogenization. Biological Conservation 127:247-260

Mitchell JC (1988) Population ecology and life histories of the freshwater turtles Chrysemys picta and Sternotherus odoratus in an urban lake Herpetological Monographs 2

NRW (2006) Use of traps for pest animal management In. Department of Natural Resources, Mines and Water, Queensland

Paul MJ, Meyer JL (2001) Streams in the urban landscape. Annual Review of Ecology and Systematics 32:333-365

Ream C, Ream R (1966) The influence of sampling methods on the estimation of population structure in painted turtles. American Midland Naturalist 75:325-338

Ross JB (2000) An Investigation of the distribution patterns of aquatic vertebrates across four sites in the upper Parramatta river catchment. In: Center for Landscape and Ecosystem Management. University of Western Sydney, Sydney, Australia

Rubin CS, Warner RE, Bouzat JL, Paige KN (2001) Population genetic structure of Blanding's turtles (Emydoidea blandingii) in an urban landscape. Biological Conservation 99:323-330

SAS Institute (1999) SAS System for Windows, Version 8.0. In. SAS Institute Inc., Cary, NC, USA.

Semlitsch RD, Bodie JR (2003) Biological criteria for buffer zones around wetlands and riparian habitats for amphibians and reptiles. Conservation Biology 17:1219-1228

Shirley AM, Goldizen AW, Jones DN, Krebs EA, Putland DA (2003) Effects of habitat characteristics and climate on the dist and colouration of Dusky Moorhens (Gallinula tenebrosa) in south-eastern Queensland. Emu 103:81-86

Southwood TRE, Henderson PA (2000) Ecological Methods. 3rd Edition. Blackwell Science, Tokyo, Japan

Spencer RJ (2001) The Murray River turtle, Emydura macquarii: population dynamics, nesting ecology and impact of the introducted red fox, Vulpes vulpes. In: School of Biological Sciences. University of Sydney, Sydney

Spencer RJ, Janzen FJ, Thompson MB (2006) Counterintuitive density-dependent growth in a long-lived vertebrate after removal of nest predators. Ecology 87:3109-3118.

Spencer RJ, Thompson MB (2005) Experimental analysis of the impact of foxes on freshwater turtle populations. Conservation Biology 19:845-854

Spencer RJ, Thompson MB, Hume ID (1998) The diet and digestive energetics of an Australian short-necked turtle, Emydura macquarii. Comparative Biochemistry and Physiology Part A 121:341-349 
Spinks PQ, Pauly GB, Crayon JJ, Bradley Shaffer H (2003) Survival of the western pond turtle (Emys marmorata) in an urban California environment. Biological Conservation 113:257-267

Stewart D (1996) Fauna Assessment of the Sherwood Arboretum. In. Prepared for Brisbane City Council, Australia

The Courier-Mail (2-3 June 2007) Big tanker clean-up bill. Reporter: Robyn Ironside. In, Queensland, pp 11

Thompson MB (1983) Populations of the Murray River tortoise Emydura (Chelodina (sic)): the effect of egg predation by the red fox, Vulpes vulpes. Australian Wildlife Research 10:363-371

Thomson JM (1978) Vertebrates of the Brisbane River Valley, Queensland, Australia. Proceedings of the Royal Society of Queensland 89:121-128

Trembath DF (2005) The comparative ecology of Krefft's River turtle Emydura krefftii in tropical north Queensland. In: Applied Ecology Research Group. University of Canberra, Canberra, Australia

UBD (2003) Brisbane, Gold Coast and Sunshine Coast Street Directory, 47th edition. In. Universal Publishers, Brisbane

Urban MC, Skelly DK, Burchsted D, Price W, Lowry S (2006) Stream communities across a rural-urban landscape gradient. Diversity \& Distributions 12:337-350

Walsh CJ, Sharpe AK, Breen PF, Sonneman JA (2001) Effects of urbanization on streams of the Melbourne region, Victoria, Australia. I. Benthic macroinvertebrate communities. Freshwater Biology 46:535-551

Wells RW (2007) Some Taxonomic and Nomenclatural Considerations on the Class Reptilia in Australia. A New Genus of the Family Chelidae from Eastern Australia. . Australian Biodiversity Record 2007:1-13

White GC (2007) Program Mark: Mark Recapture Survival Rate Estimation. In. Colorado State University, CO, USA

White M (2002) The Cooper Creek turtle persisting under pressure: a study in arid Australia. In: Applied Ecology Research Group. University of Canberra, Canberra

Your Suburb: Mackenzie (2007) Web address: http://www.yoursuburb.com.au/4156/mackenzie/web/index.asp. Starbug Pty Ltd. Accessed on 4-5-07. In: 
Table 1: Location, approximate age, origin and size of lakes surveyed in Brisbane, Australia

\begin{tabular}{lllll}
\hline Lake name & Suburb & Origin & Age of lake & Area (ha) \\
\hline Dennis Lake & Daisy Hill & Natural lagoons & Unknown, modified 1920s, 1950s & 1.15 \\
Edenbrooke Estate & Sinnamon Park & Small polluted creek (Jindalee Ck) & 2001 & 0.66 \\
Gainsborough Park & Makenzie & Runoff gully or very small creek & $\sim 1994$ & 0.51 \\
Lakewood Estate & Parkinson & Small creek (part of Oxley Ck catchment) & 1994 & 0.99 \\
Minnippi Parklands & Tingalpa & Creek or farm dam & Unknown, modified? & 4.11 \\
Mt Coot-tha Botan. G. & Mt Coot-tha & Vegetated gully & 1970 & 0.37 \\
Sherwood Arboretum & Sherwood & Swamp with creek flowing through & Remodelled 1974 & 0.70 \\
Underwood Park & Priestdale & Natural Creek or lagoon? & Unknown & 0.60
\end{tabular}


Table 2: Species of turtles captured in Brisbane lakes, as well as numbers of captures and recaptures and percentage of total.

\begin{tabular}{|c|c|c|c|c|}
\hline Common Name & Scientific Name & Captures & Recaptures & Individuals \\
\hline Broad-shelled turtle & Chelodina expansa & 48 & 7 & $41(11.1 \%)$ \\
\hline Snake-necked turtle & Chelodina longicollis & 3 & 0 & $3(0.8 \%)$ \\
\hline Saw-shelled turtle & Wollumbinia latisternum $^{\mathrm{b}}$ & 43 & 6 & $37(10 \%)$ \\
\hline Brisbane River turtle & Emydura macquarii signata & 346 & 60 & $286(77.7 \%)$ \\
\hline Red-eared slider turtle $^{\mathrm{a}}$ & Trachemys scripta elegans & 1 & 0 & $1(0.3 \%)$ \\
\hline Total & & 441 & 73 & 368 \\
\hline
\end{tabular}

${ }^{\mathrm{a}}$ Introduced species

${ }^{\mathrm{b}}$ Recently changed from Elseya latisternum (Wells 2007) 
Table 3: The number of turtles at each lake for maturity level, sex and presence of eggs in females.

\begin{tabular}{lccccccccc}
\hline & DL & EE & GP & LE & MP & MC & SA & UP & Total \\
\hline Juveniles & 16 & 19 & 26 & 5 & 41 & 1 & 2 & 11 & 121 \\
Adults & 13 & 30 & 10 & 29 & 45 & 13 & 68 & 35 & 243 \\
\hline Males & 10 & 10 & 4 & 12 & 29 & 7 & 26 & 24 & 122 \\
Females & 3 & 20 & 6 & 17 & 16 & 6 & 42 & 11 & 121 \\
\hline Gravid females & 1 & 7 & 4 & 8 & 4 & 2 & 22 & 3 & 51 \\
Not gravid females & 2 & 13 & 2 & 9 & 12 & 4 & 20 & 8 & 71 \\
\hline
\end{tabular}


Table 4: Estimated population size and number of captured individuals at each lake generated by the CAPTURE program.

\begin{tabular}{|c|c|c|c|c|c|c|c|c|c|c|}
\hline & \multicolumn{3}{|c|}{ Brisbane river turtle } & \multicolumn{3}{|c|}{ Saw-shelled turtle } & \multicolumn{3}{|c|}{ Broad-shelled turtle } & \multirow{2}{*}{$\begin{array}{l}\text { Est. } \\
\text { Total }\end{array}$} \\
\hline & Pop Est & SE & Captured & Pop Est & SE & Captured & Pop Est & SE & Captured & \\
\hline Dennis Lake & 34 & 8.189 & 23 & 4.5 & 1.287 & 4 & 3.2 & 1.842 & 2 & 41.7 \\
\hline Edenbrooke Estate & 100 & 39.487 & 36 & 7.8 & 2.463 & 8 & 4.67 & 1.512 & 4 & 112.5 \\
\hline Gainsborough Park & 79 & 14.269 & 34 & & & 0 & 4.67 & 1.279 & 2 & 83.7 \\
\hline Lakewood Estate & 77 & 25.928 & 31 & 5.0 & 1.862 & 3 & & & 0 & 82 \\
\hline Minnippi Parklands & 241 & 27.39 & 73 & & & 0 & 31 & 8.387 & 13 & 272 \\
\hline Mt Coot-tha & 7.5 & 2.47 & 5 & 18 & 5.646 & 8 & & & 0 & 25.5 \\
\hline Sherwood Arboretum & 93 & 19.9 & 60 & 7 & 3.405 & 5 & 8 & 3.513 & 5 & 108 \\
\hline Underwood Park & 53 & 12.6 & 22 & 9 & 0.293 & 9 & 32 & 8.781 & 15 & 94 \\
\hline
\end{tabular}




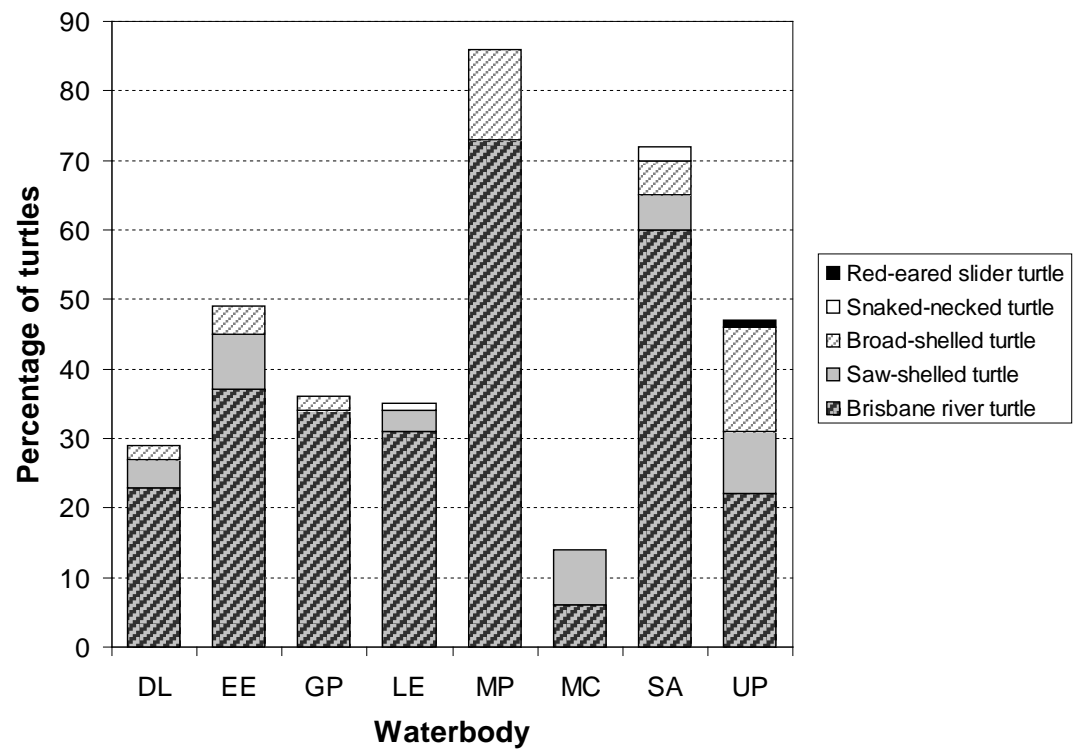

Figure 1: Total captures of turtles for each lake in Brisbane, Australia. 

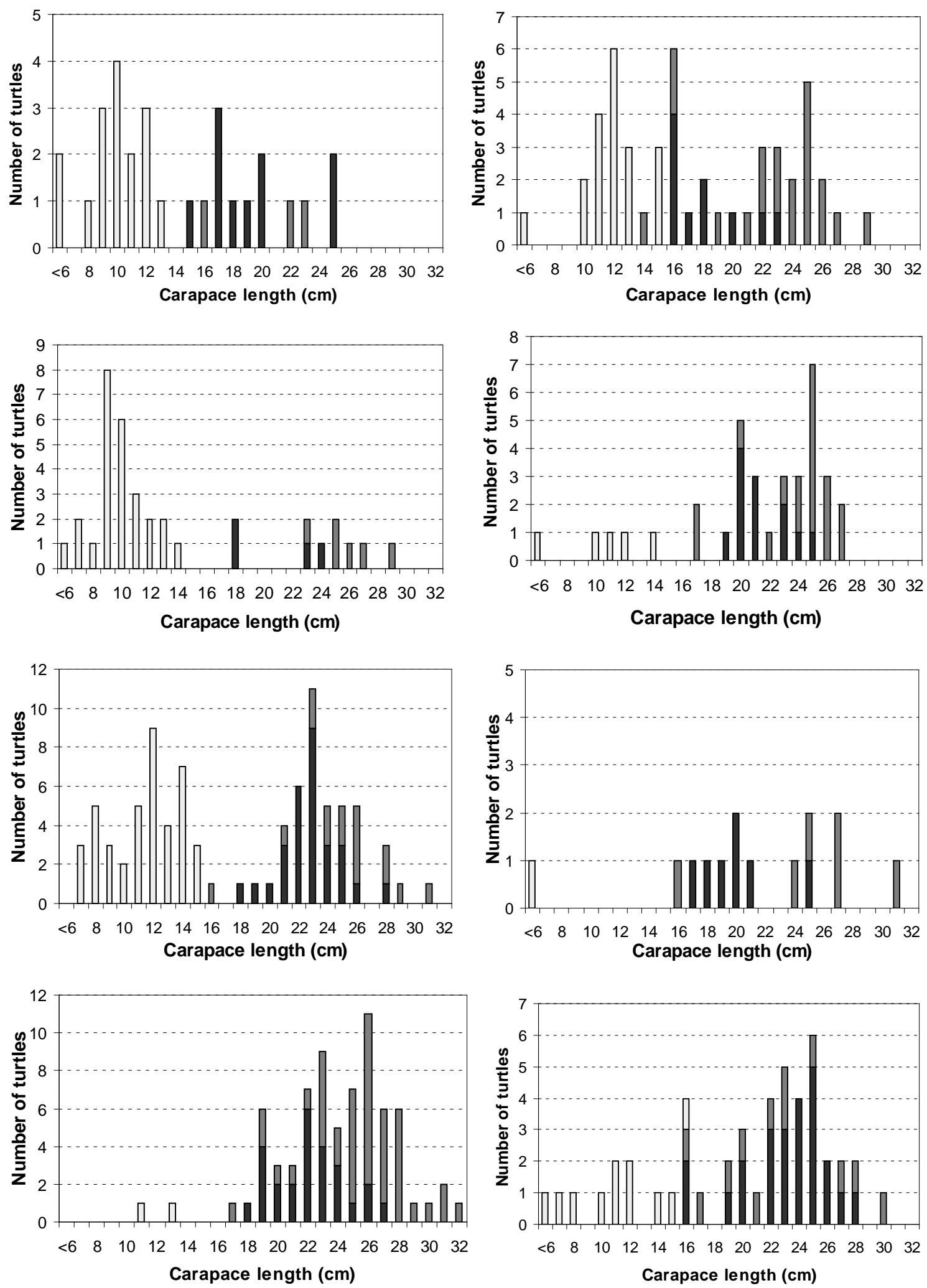

Figure 2: Size distribution of males ( $\square$ ), females ( $\square$ ) and juveniles ( $\square$ ) at each lake, all species grouped together (a) Dennis Lake ( $\mathrm{n}=29$ ), (b) Edenbrooke Estate ( $\mathrm{n}=49$ ), (c) Gainsborough Park (n=36), (d) Lakewood Estate (n=35), (e) Minnippi Parklands (n=86), (f) Mt Coot-tha Botanical Gardens ( $n=14)$, (g) Sherwood Forest Arboretum (n=72), (h) Underwood Park $(n=47)$. 


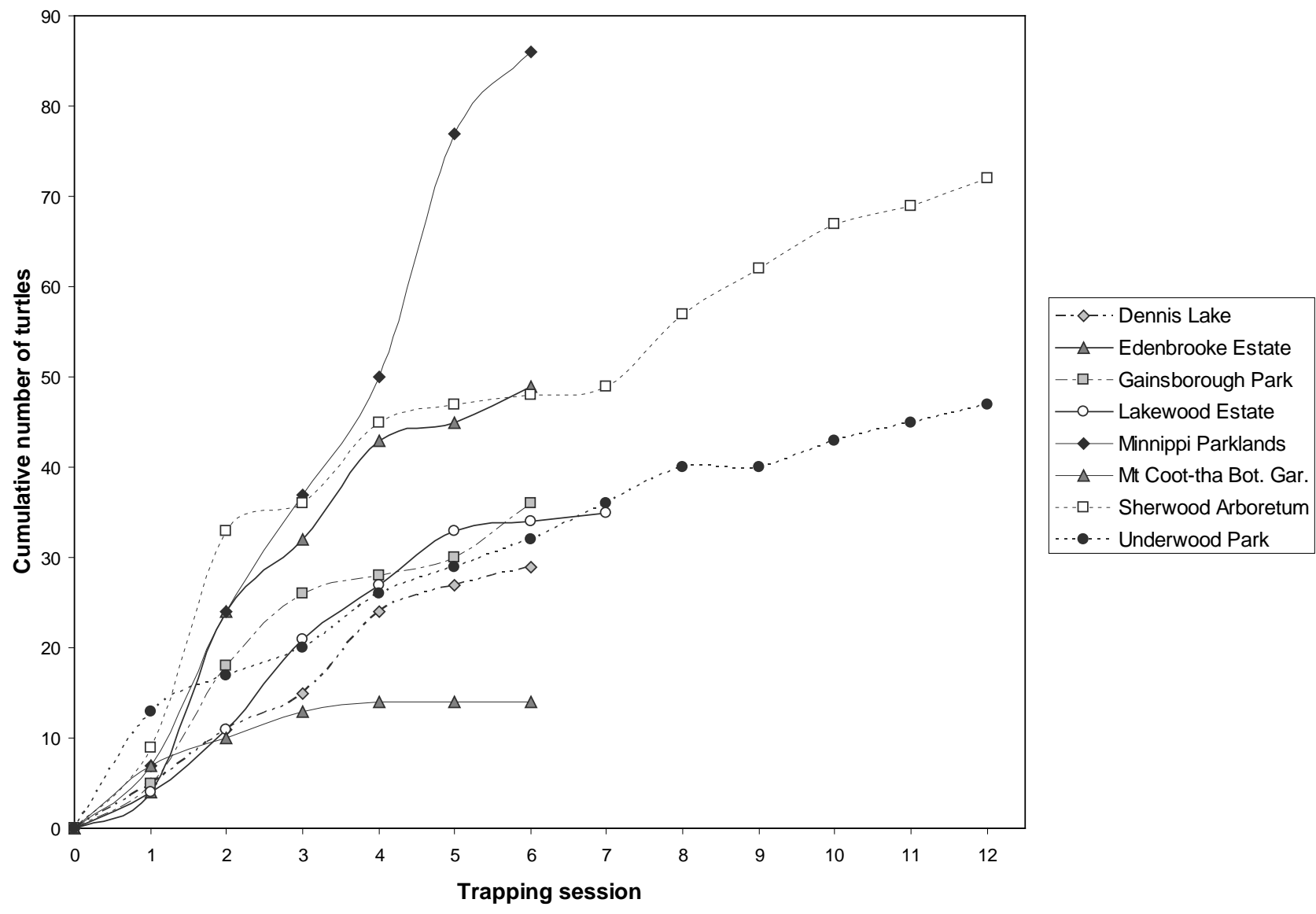

Figure 3: Cumulative individual turtle curve for each lake. 


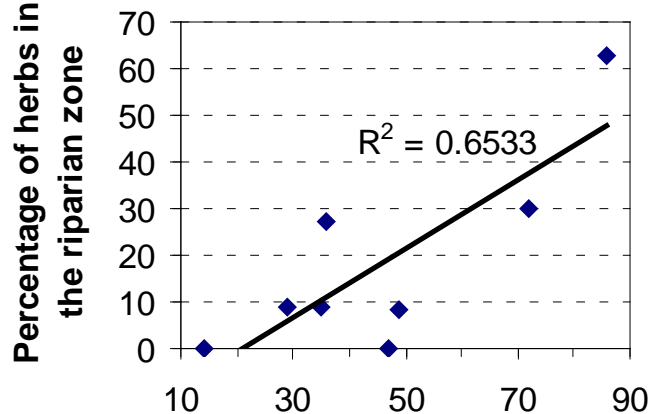

(a)

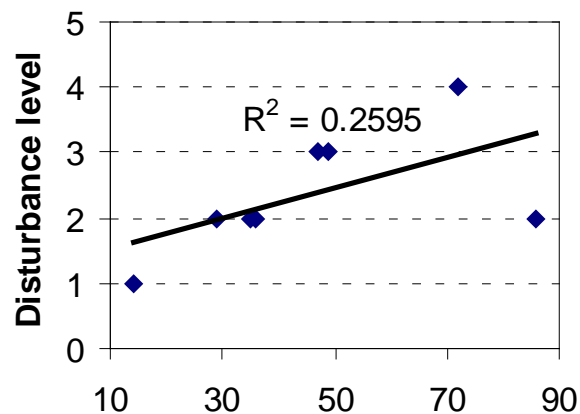

(b) Number of turtles

Figure 4: (a) Relationship between the percentage of herbs at the lake and the total number of turtles captured ( $\mathrm{f}=11.31, \mathrm{df}=1, \mathrm{p}=0.0152$, Partial $\mathrm{R}^{2}=0.6533$ ). (b) Relationship between the disturbance level at the lake and the total number of turtles captured $\left(\mathrm{f}=14.87, \mathrm{df}=2, \mathrm{p}=0.0119\right.$, Partial $\mathrm{R}^{2}=0.2595$ ). 

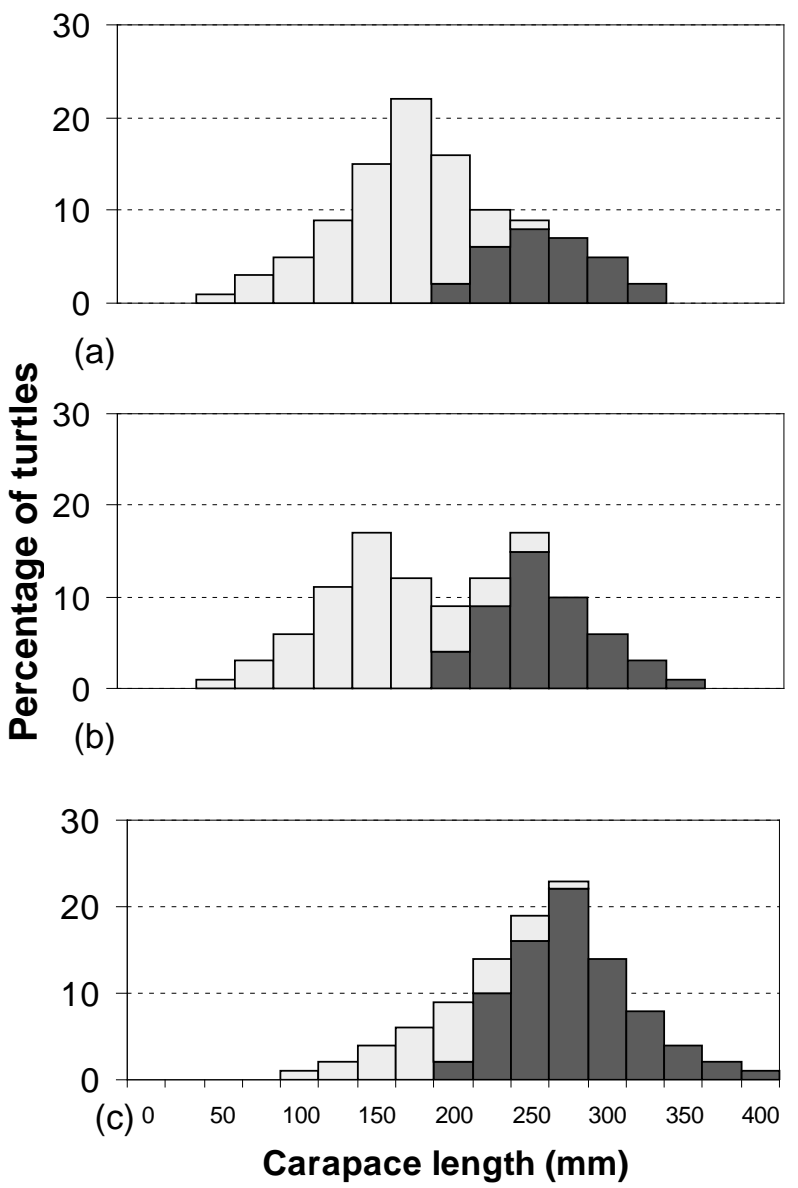

Figure 5: Examples of size distribution for (a) recovering (or nascent), (b) intermediate and (c) climax populations of turtles, showing juveniles ( $\square$ ) and adults ( $\square$ )(adapted from Georges et al. 2005). 